\title{
NUMERICAL SIMULATIONS OF RIDGE ACCRETION AND ONSHORE MIGRATION BASED ON FIELD DATA FROM A STEEP MESO-TIDAL ENGINEERED BEACH
}

\author{
Youn Kyung Song, Texas A\&M University, yksong@tamu.edu \\ Jens Figlus, Texas A\&M University, figlusj@tamu.edu \\ Patricia Chardón-Maldonado, University of Puerto Rico, patricia.chardon@upr.edu \\ Jack A. Puleo, University of Delaware, ipuleo@UDel.Edu
}

\section{BACKGROUND}

Previously, the accretion of a slip-faced ridge and runnel (RR) system was observed during a 3-week field experiment on a steep meso-tidal engineered beach at South Bethany Beach, Delaware. Detailed measurements of wading depth beach profiles and nearbed flow velocities were obtained in the inner surf and swash zones along with offshore wave and current records. In the beginning of this 3-week field campaign on February 13, 2014 a Nor'easter eroded significant portions of the inner beach during this 1-day long storm event. Immediately after the storm during the less energetic conditions, the rapid formation of a pronounced RR system was observed which then continuously evolved over the duration of 2-week poststorm recovery periods. In the last day of the field campaign, $85 \%$ of the sediment volume eroded during the storm was recovered in the swash zone. However, no more evolution of the RR system toward the runnel infilling or landward migration was observed.

\section{NUMERICAL EXPERIMENTS}

The overall beach dynamics associated with the formation and landward migration of the slip-face RR systems are studied using a numerical process-based morphodynamics model CSHORE (Johnson et al., 2009; Figlus et al., 2012). Two numerical modeling strategies were implemented: First, the observed RR system formation and growth from the measured profiles were reproduced with the model in order to study detailed morphodynamic processes associated with a pronounced RR system accretion under a minor influence of wave overtopping. Next, the CSHORE model predicted the landward migration of the RR system assuming significant wave overtopping and overwash across the accreting ridge crest.

\section{RESULTS AND OUTLOOK}

Figure 1 shows the CSHORE profiles predicting the accretion and migration of the RR system, compared with the field measurement after subsidence of the storm. Once properly calibrated, CSHORE was able to accurately predict the evolution of the crest location and elevation, and seafront slope of the accreting ridge with efficiency: The modeled profile matched the measured seafront slope with lower than $6 \%$ error and the rootmean-square differences between the measured and modeled profile elevations of $0.22 \mathrm{~m}$. Simulation times were a matter of a few seconds (an order of 10-3 of the measurement duration) for over 28 tidal cycles. However, the model required a slightly longer period of simulation time (about 4 additional tidal cycles) for the accreting ridge to achieve the $85 \%$ of sediment volume recovery observed in the field.

On the other hand, with enhanced effects of wave overtopping, CSHORE predicted the RR system to migrate landward as more rapidly building-up ridge crest were quickly overwashed within the first 3 tidal cycles and sediments carried onshore filled in the landward runnel. In the end, the upper beach profiles were reestablished in a new berm and dune template and $81 \%$ of eroded volume was estimated to be recovered during the 2-week of post-storm, subsidence wave condition. Overall, the CSHORE predictions on swash inundation depth, cross-shore extension of runup, and associated cross-shore mean water velocity reasonably represented the field measurements and are discussed in light of the model calibration strategy and future modifications.

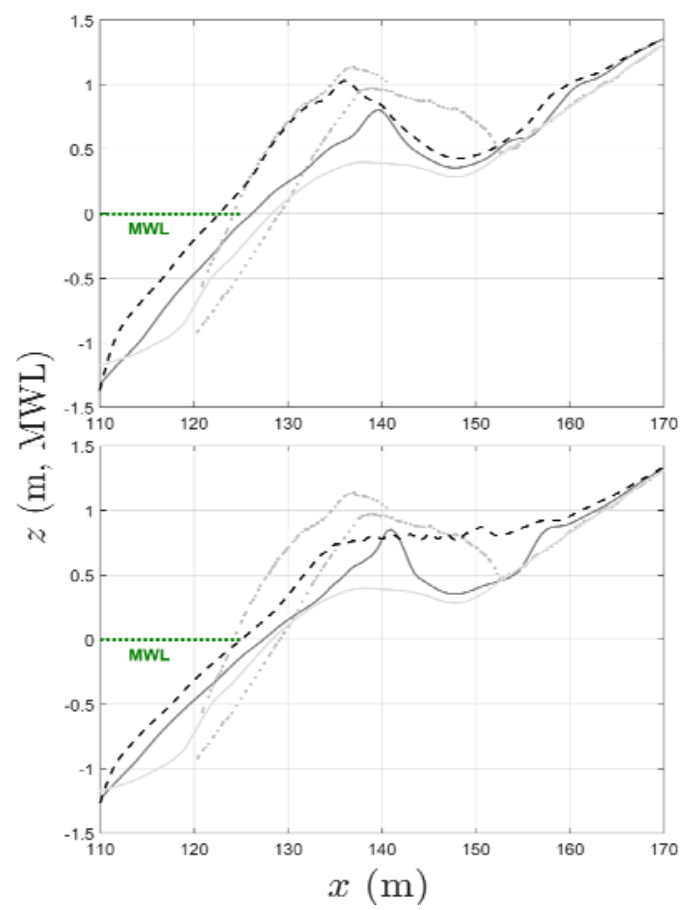

Figure 1 - Evolution of the slip-faced Ridge-Runnel (RR) system at Bethany Beach after the Nor'Easter Storm on February 13th, 2014, Delaware. The CSHORE profiles predicting the accretion (top) and landward migration (bottom) of the RR system during the 2-week of post-storm recovery period are compared with the measured profiles (dotted) obtained during the field campaign.

\section{REFERENCES}

Figlus, J., Kobayashi, N., \& Gralher, C. (2011). Onshore migration of emerged ridge and ponded runnel. Journal of Waterway, Port, Coastal, and Ocean Engineering, 138(5), pp 331-338

Johnson, B. D., Kobayashi, N., and Gravens, M. B. (2012). Cross-Shore Numerical Model CSHORE for Waves, Currents, Sediment Transport and Beach Profile Evolution, Final Rep. No. ERDC/CHL TR-12-22, U.S., Army Corps of Engineers, Coastal and Hydraulics Laboratory, Vicksburg, MS. 